\title{
Manioc anaphylaxis in a patient sensitised to latex
}

\author{
Isabel Carrapatso ${ }^{1 *}$, Borja Bartolome ${ }^{2}$, Filipa Ribeiro ${ }^{1}$, António Segorbe Luís ${ }^{1}$ \\ From Food Allergy and Anaphylaxis Meeting 2011 \\ Venice, Italy. 17-19 February 2011
}

\section{Background}

We report the case of a 51 years old female that suffered from a systemic anaphylactic episode 5 minutes after the ingestion of manioc at the age of 50 . This patient reported rhinoconjunctivitis since she was 20 years-old after contact with latex gloves and rhinoconjunctivitis and oral allergy syndrome after the ingestion of kiwi, banana and mango since the age of 30 . The patient had also a history of eight surgeries since the age of 24 years-old.

\section{Methods}

Skin prick tests (SPT) to commercial extracts of aeroallergens and food allergens were carried out. Prick-toprick tests (PP) and specific IgE determinations (sIgE) to some plant foods were also performed, according to case history. The molecular mass of the IgE binding bands was calculated by means of SDS PAGE immunoblotting. In order to study the presence of cross reacting IgE in the patient serum we carried out a SDS-PAGE immunoblotting-inhibition assay using manioc extract in solid phase and banana and latex as inhibitors. Furthermore, we carried out an immunoblotting inhibition assay using banana extract in solid phase and latex and manioc as inhibitors.

\section{Results}

SPT and/or PP were positive to latex, manioc, chestnut, kiwi, tomato, banana and mango. Serum specific IgE was positive to latex $(4.98 \mathrm{kU} / \mathrm{L})$, Gold kiwi $(0.4 \mathrm{kU} / \mathrm{L})$ and banana $0.9 \mathrm{kU} / \mathrm{L}$. The apparent molecular mass of the IgE binding bands on SDS PAGE immunoblotting assays were as follow: extract from mandioc pulp: 31 $\mathrm{kDa}$; extract from latex: $55 \mathrm{kDa} ; 39 \mathrm{kDa} ; 34 \mathrm{kDa} ; 25$ $\mathrm{kDa} ; 20 \mathrm{kDa}$; $14 \mathrm{kDa}$; extract from Gold kiwi: $34 \mathrm{kDa}$;

${ }^{1}$ Coimbra University Hospital, Imunoallergy Department, Coimbra, Portugal Full list of author information is available at the end of the article extract from banana: $34 \mathrm{kDa} ; 32 \mathrm{kDa}$. A total IgE binding inhibition on $31 \mathrm{kDa}$ manioc protein was detected when banana and latex extracts were used as inhibitors. When banana extract was used in solid phase a total IgE binding inhibition with latex was observed.

\section{Conclusions}

Immunoblotting-inhibition assays proved a maniocbanana- latex cross reactive syndrome in this patient. We believe that, in this case, the primary sensitization agent is latex.

\section{Author details}

${ }^{1}$ Coimbra University Hospital, Imunoallergy Department, Coimbra, Portugal. ${ }^{2}$ Bial-Aristegui, R\&D Department, Bilbao, Spain.

Published: 12 August 2011

doi:10.1186/2045-7022-1-S1-P52

Cite this article as: Carrapatso et al:: Manioc anaphylaxis in a patient sensitised to latex. Clinical and Translational Allergy 2011 1(Suppl 1):P52.

Submit your next manuscript to BioMed Central and take full advantage of:

- Convenient online submission

- Thorough peer review

- No space constraints or color figure charges

- Immediate publication on acceptance

- Inclusion in PubMed, CAS, Scopus and Google Scholar

- Research which is freely available for redistribution

\section{Ciomed Central}

